\title{
Succinic Acid As a Green and Bio-Based Catalyst assisted solvent-free one-pot Biginelli synthesis of biologically active 3,4-dihydropyrimidin-2-(1H)-ones/thiones derivatives
}

\author{
Farzaneh Mohamadpour ${ }^{1 *}$ and Mansoor Feilizadeh ${ }^{2}$
}

\begin{abstract}
${ }^{1}$ Young Researchers and Elite Club, Shiraz Branch, Islamic Azad University, Shiraz, Iran

${ }^{2}$ Department of Chemical Engineering, Faculty of Engineering, Ferdowsi University of Mashhad, Mashhad, Iran

*Corresponding author.E-mail: mohamadpour.f.7@gmail.com

https://doi.org/10.12982/CMUJNS.2019.0034
\end{abstract}

Received: February 21, 2019

Revised: April 4, 2019

Accepted: April 24, 2019

\begin{abstract}
Succinic acid as a bio-based green and versatile catalyst has been employed for one-pot facile three-component Biginelli synthesis of 3,4dihydropyrimidin-2-(1H)-ones/thiones derivatives under solvent-free conditions with high to excellent yields and short reaction times. This sustainable procedure has notable benefits such as easy-to-handle, green, low-cost and non-toxic catalyst, materials available, simple work-up with no necessity of chromatographic purification steps, one-pot and solvent-free conditions. The products have been characterized by melting points and ${ }^{1} H$ NMR spectroscopy.
\end{abstract}

Keywords: Succinic acid, 3,4-dihydropyrimidin-2-(1H)-ones/thiones derivatives, Sustainable procedure, Biginelli condensation reaction, Solvent-free conditions.

\section{INTRODUCTION}

Succinic acid $\left(\mathrm{C}_{4}\right.$-dicarboxylic acid) (Figure 1$)$ is a common metabolite in plants, animals and microorganisms and has been used widely in agricultural, food and pharmaceutical industries (Zeikus et al., 1999). This acid has holds good industrial applications and is used in industries such as, resins, polymer, paints, cosmetics and inks, etc(Vermuri et al., 2002). To date, the economically renewable resources used in succinic acid production reported are cheese whey 
(Samuelov., 1999; Lee et al., 2000; Lee et al., 2003a; Wan et al., 2008), cane molasses (Agarwal., 2006; Liu et al., 2008), Jerusalem artichoke (Zheng et al., 2010), wheat flour (Du et al., 2008), wood hydrolysate (Lee., 2003b; Kim et al., 2004; Hodge et al., 2009) and corn straw hydrolysate (Zheng et al., 2009).

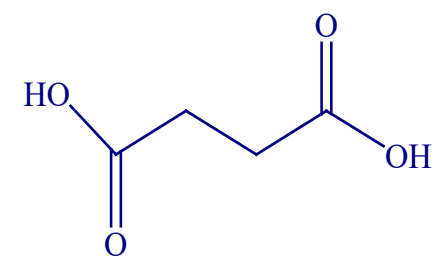

Figure 1. Structure of succinic acid.

One of the dominating factors in recent organic synthetic routs is green chemistry. Atom economy, reduction in byproduct, number of steps in organic synthesis, energy cost, produced waste, use of non-hazardous reagents in catalytic protocols are one of the most important goals of green chemistry. Furthermore, organic reactions under solvent-free conditions for green and clean synthesis of organic compounds have attracted much interest in organic chemists. And herein, our recent studies focused on developing of green catalyst (Mohamadpour, 2018a; Mohamadpour et al., 2018b; Mohamadpour et al., 2018c) in multi-component reactions (Mohamadpour et al., 2016; Mohamadpour et al., 2017; Lashkari et al., 2018).

Pyrimidinone derivatives are a common structural motif in variety of natural and non-natural products. Their derivatives have been known to exhibit a wide range of pharmacological and biological properties. For example these heterocyclic compounds have been used as calcium channel blockers, $\alpha-1$ aantagonists (Prakash et al., 2008), mitotic kinesin Eg5 inhibition (Kapoor et al., 2000), anti cancer (Mal3-101) (Wisen et al., 2008), anti HIV agent (Heys et al., 2000), antibacterial and antifungal (Ashok et al., 2007), antiviral (Hurst et al., 1961), antioxidative (Magerramow et al., 2006). The representatives such as batzelladines, ptilomycalines and crambescidines exhibit many biological activities such as anticancer, antifungal, anti HIV etc (Bewley et al., 2004).

Recently, numerous protocols for the preparation of these compounds that is including various catalysts have been reported calcium fluoride (Chitra et al., 2009), copper(II)sulfamate (Liu et al., 2009), baker's yeast (Kumar et al., 2007), hydrotalcite (Lal et al., 2012), hexaaquaaluminium (III) tetrafluoroborate (Litvic et al., 2010), TBAB (Ahmad et al., 2009), copper (II) tetrafluoroborate (Kamal et al., 2007), Copper (II) acetate (Khodja et al., 2014), [Btto][p-TSA] (Zhang et al., 2015), triethylammonium acetate (Attri et al., 2017), $p$-dodecyl- 
benzenesulfonic acid (Aswin et al., 2014) and TMSPTPOSA (Rao Jetti et al., 2017). Some of the limitations of these methodologies are low yields, toxic organic solvents and catalyst, harsh reaction conditions and expensive materials. Based on the above considerations and in continuation of our efforts to develop green methodologies, we reported herein succinic acid as a bio-based green catalytic system for the synthesis of 3, 4-dihydropyrimidin-2-(1H)-ones/ thiones derivatives via three-component Biginelli (Biginelli et al., 1893) reaction between $\beta$-keto esters, aldehyde derivatives and urea/thiourea under thermal and solvent-free conditions with high to excellent yields and short reaction times (Figure 1). One of the source of environmental pollutions is the usage of organic solvents under reflux conditions and the need for column chromatography to purity the products. In this present work, the products were obtained through simple filtering with no need column chromatographic separation. The advantages of succinic acid as a bio-based, mild and green acidic catalyst in organic synthesis are eco-safe, highly efficient, easily to handle, and inexpensive.

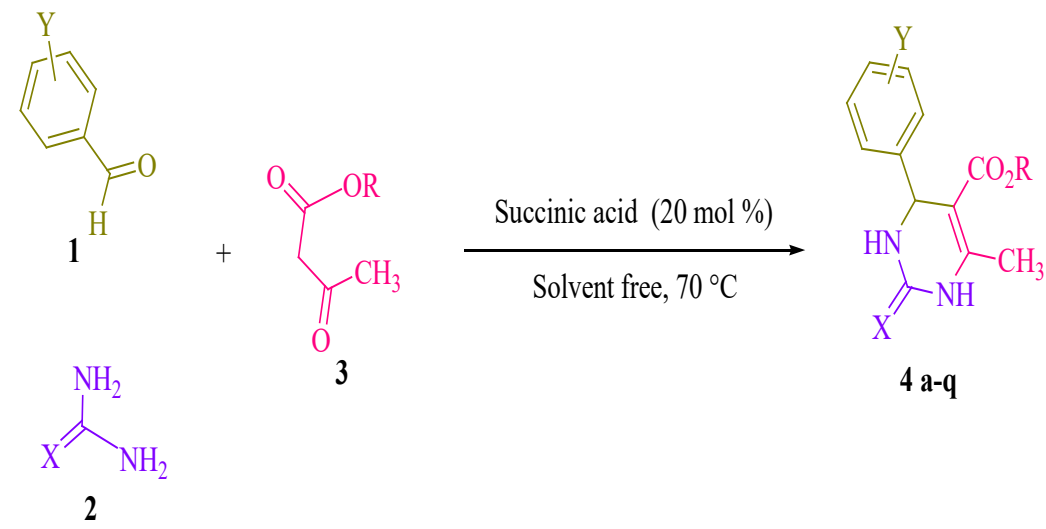

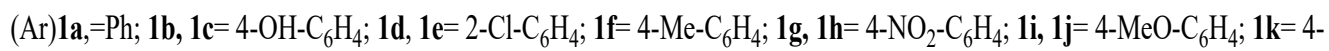

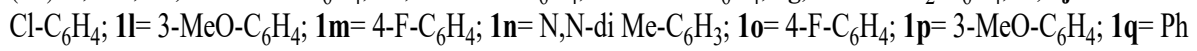

(X) $2 \mathrm{a}=0 ; \mathbf{2 b}=\mathrm{S}$

(R) $\mathbf{3} \mathbf{a}=\mathrm{Et} ; \mathbf{3} \mathbf{b}=\mathrm{Me}$

Figure1. Synthesis of 3, 4-dihydropyrimidin-2-(1H)-ones/thiones derivatives. 


\section{MATERIALS AND METHODS}

\section{General}

Melting points all compounds were determined using an Electro thermal 9100 apparatus. ${ }^{1} \mathrm{H}$ NMR spectra were recorded on a Bruker DRX-400 Avance instruments with DMSO- $\mathrm{d}_{6}$ as solvents. All reagents and solvents were purchased from Merck, Fluka and Acros chemical companies were used without further purification.

General procedure for preparation of 3, 4-dihydropyrimidin-2(1H)-ones/thiones derivatives (4a- q). A mixture of aldehyde derivatives (1, $1.0 \mathrm{mmol})$ and urea/thiourea $(2,1.5 \mathrm{mmol})$, ethyl/methyl acetoacetate $(3,1.0$ $\mathrm{mmol}$ ) was heated under solvent-free conditions at $70{ }^{\circ} \mathrm{C}$ for appropriate time in the presence of succinic aicd (20 mol \%). After completion of the reaction (by thin layer chromatography TLC) the mixture was cooled to rt and cold water was added and the precipitated was separated with filtration and recrystallized from ethanol to afford the pure products (4a- q). Spectra data of products are represented below:

\section{5-Ethoxycarbonyl-6-methyl-4-phenyl-3,4-dihydropyrimidin-2(1H)-one (4a)}

Crystalline solid; Yield: 91\%; M.p. 199-200 ${ }^{\circ} \mathrm{C} ;{ }^{1} \mathrm{H}$ NMR (400 MHz, DMSO-d 6 ): $1.10\left(3 \mathrm{H}, \mathrm{t}, J=7.2 \mathrm{~Hz}, \mathrm{CH}_{3} \mathrm{CH}_{2}\right), 2.26\left(3 \mathrm{H}, \mathrm{s}, \mathrm{CH}_{3}\right), 3.99(2 \mathrm{H}, \mathrm{q}, J=7.2 \mathrm{~Hz}$, $\left.\mathrm{CH}_{2} \mathrm{O}\right), 5.15(1 \mathrm{H}, \mathrm{s}, \mathrm{CHN}), 7.26(3 \mathrm{H}, \mathrm{d}, J=7.2 \mathrm{~Hz}, \mathrm{ArH}), 7.33(2 \mathrm{H}, \mathrm{t}, J=7.2 \mathrm{~Hz}$, $\mathrm{ArH}), 7.76$ and $9.21(2 \mathrm{H}, 2 \mathrm{~s}, 2 \mathrm{NH})$.

\section{5-Ethoxycarbonyl-6-methyl-4-(4-hydroxyphenyl)-3,4-dihydropyrimidin-2} (1H)-one (4c)

Crystalline solid; Yield: 81\%; M.p. 232-234 ${ }^{\circ} \mathrm{C}$; ${ }^{1} \mathrm{H}$ NMR $(400 \mathrm{MHz}, \mathrm{DM}-$ SO-d $)_{6}: 1.11\left(3 \mathrm{H}, \mathrm{t}, J=9.6 \mathrm{~Hz}, \mathrm{CH}_{3} \mathrm{CH}_{2}\right), 2.50\left(3 \mathrm{H}, \mathrm{s}, \mathrm{CH}_{3}\right), 3.98(2 \mathrm{H}, \mathrm{q}, J=9.2$ $\left.\mathrm{Hz}, \mathrm{CH}_{2} \mathrm{O}\right), 5.04(1 \mathrm{H}, \mathrm{s}, \mathrm{CHN}), 6.68-7.04(4 \mathrm{H}, \mathrm{m}, \mathrm{ArH}), 7.64$ and $9.13(2 \mathrm{H}, 2 \mathrm{~s}$, $2 \mathrm{NH}), 9.35(1 \mathrm{H}, \mathrm{s}, \mathrm{OH})$.

\section{5-Methoxycarbonyl-6-methyl-4-(2-chlorophenyl)-3,4-dihydropyrimidin- 2(1H)-one (4d)}

Crystalline solid; Yield: 85\%; M.p.251-253 ${ }^{\circ} \mathrm{C}$; ${ }^{1} \mathrm{H}$ NMR (400 MHz, DMSO-d 6 ): $2.31\left(3 \mathrm{H}, \mathrm{s}, \mathrm{CH}_{3}\right), 3.46\left(3 \mathrm{H}, \mathrm{s}, \mathrm{OCH}_{3}\right), 5.62(1 \mathrm{H}, \mathrm{s}, \mathrm{CHN}), 7.28-7.34(3 \mathrm{H}, \mathrm{m}$, ArH), $7.42(1 \mathrm{H}, \mathrm{d}, J=7.2 \mathrm{~Hz}, \mathrm{ArH}), 7.72$ and $9.36(2 \mathrm{H}, 2 \mathrm{~s}, 2 \mathrm{NH})$. 
5- Ethoxycarbonyl-6-methyl-4-(2-chlorophenyl)-3,4-dihydropyrimidin-2(1H)one (4e)

Crystalline solid; Yield: 82\%; M.p. 220-222 ${ }^{\circ} \mathrm{C}$; ${ }^{1} \mathrm{H}$ NMR (400 MHz, DMSO-d $): 1.00\left(3 \mathrm{H}, \mathrm{t}, J=9.2 \mathrm{~Hz}, \mathrm{CH}_{3} \mathrm{CH}_{2}\right), 2.31\left(3 \mathrm{H}, \mathrm{s}, \mathrm{CH}_{3}\right), 4.02(2 \mathrm{H}, \mathrm{q}, J=9.2$ $\left.\mathrm{Hz}, \mathrm{CH}_{2} \mathrm{O}\right), 5.63(1 \mathrm{H}, \mathrm{s}, \mathrm{CHN}), 7.25-7.34(3 \mathrm{H}, \mathrm{m}, \mathrm{ArH}), 7.41(1 \mathrm{H}, \mathrm{d}, J=8.8 \mathrm{~Hz}$, $\mathrm{ArH}), 7.73$ and $9.29(2 \mathrm{H}, 2 \mathrm{~s}, 2 \mathrm{NH})$.

5-Methoxycarbonyl-6-methyl-4-(4-nitrophenyl)-3,4-dihydropyrimidin-2(1H)one (4g)

Crystalline solid; Yield: 92\%; M.p.212-214 ${ }^{\circ} \mathrm{C} ;{ }^{1} \mathrm{H}$ NMR (400 MHz, DMSO-d 6 ): $2.28\left(3 \mathrm{H}, \mathrm{s}, \mathrm{CH}_{3}\right), 3.55\left(3 \mathrm{H}, \mathrm{s}, \mathrm{OCH}_{3}\right), 5.28(1 \mathrm{H}, \mathrm{s}, \mathrm{CHN}), 7.52(2 \mathrm{H}, \mathrm{d}, J=8.4 \mathrm{~Hz}$, $\mathrm{ArH}), 7.22(2 \mathrm{H}, \mathrm{d}, J=8.8 \mathrm{~Hz}, \mathrm{ArH}), 7.93$ and $9.40(2 \mathrm{H}, 2 \mathrm{~s}, 2 \mathrm{NH})$.

5-Ethoxycarbonyl-6-methyl-4-(4-nitrophenyl)-3,4-dihydropyrimidin-2(1H)one (4h)

Crystalline solid; Yield: 90\%; M.p. 206-208 ${ }^{\circ} \mathrm{C} ;{ }^{1} \mathrm{H}$ NMR (400 MHz, DMSO-d ${ }_{6}$ ): $1.10\left(3 \mathrm{H}, \mathrm{t}, J=9.6 \mathrm{~Hz}, \mathrm{CH}_{3} \mathrm{CH}_{2}\right), 2.28\left(3 \mathrm{H}, \mathrm{s}, \mathrm{CH}_{3}\right), 3.99\left(2 \mathrm{H}, \mathrm{q}, J=9.2 \mathrm{~Hz}, \mathrm{CH}_{2} \mathrm{O}\right)$, $5.27(1 \mathrm{H}, \mathrm{s}, \mathrm{CHN}), 7.50-7.53(2 \mathrm{H}, \mathrm{m}, \mathrm{ArH}), 7.23(2 \mathrm{H}, \mathrm{d}, J=9.2 \mathrm{~Hz}, \mathrm{ArH}), 7.92$ and $9.38(2 \mathrm{H}, 2 \mathrm{~s}, 2 \mathrm{NH})$.

5-Ethoxycarbonyl-6-methyl-4-(4-methoxyphenyl)-3,4-dihydropyrimidin-2 (1H)-one (4j)

Crystalline solid; Yield: 84\%; M.p.205-207 ${ }^{\circ} \mathrm{C} ;{ }^{1} \mathrm{H}$ NMR (400 MHz, DMSO-d 6 ): $1.11\left(3 \mathrm{H}, \mathrm{t}, J=9.6 \mathrm{~Hz}, \mathrm{CH}_{3} \mathrm{CH}_{2}\right), 2.24\left(3 \mathrm{H}, \mathrm{s}, \mathrm{CH}_{3}\right), 3.73\left(3 \mathrm{H}, \mathrm{s}, \mathrm{OCH}_{3}\right), 3.99$ $\left(2 \mathrm{H}, \mathrm{q}, J=9.6 \mathrm{~Hz}, \mathrm{CH}_{2} \mathrm{O}\right), 5.09(1 \mathrm{H}, \mathrm{s}, \mathrm{CHN}), 6.89(2 \mathrm{H}, \mathrm{d}, \mathrm{J}=8.4 \mathrm{~Hz}, \mathrm{ArH}), 7.15$ $(2 \mathrm{H}, \mathrm{d}, J=8.8 \mathrm{~Hz}, \mathrm{ArH}), 7.70$ and $9.18(2 \mathrm{H}, 2 \mathrm{~s}, 2 \mathrm{NH})$.

5-Ethoxycarbonyl-6-methyl-4-phenyl-3,4-dihydropyrimidin-2(1H)-thione (4q) Crystalline solid; Yield: 89\%; M.p.210-212 ${ }^{\circ} \mathrm{C}$; ${ }^{1} \mathrm{H}$ NMR (400 MHz, DMSO-d 6 ): $1.11\left(3 \mathrm{H}, \mathrm{t}, J=7.2 \mathrm{~Hz}, \underline{\mathrm{CH}}_{3} \mathrm{CH}_{2}\right), 2.31\left(3 \mathrm{H}, \mathrm{s}, \mathrm{CH}_{3}\right), 4.02(2 \mathrm{H}, \mathrm{q}, J=7.2 \mathrm{~Hz}$, $\left.\mathrm{CH}_{2} \mathrm{O}\right), 5.19(1 \mathrm{H}, \mathrm{s}, \mathrm{CHN}), 7.23(2 \mathrm{H}, \mathrm{d}, J=7.2 \mathrm{~Hz}, \mathrm{ArH}), 7.28(1 \mathrm{H}, \mathrm{t}, J=7.2 \mathrm{~Hz}$, $\mathrm{ArH}), 7.36(2 \mathrm{H}, \mathrm{t}, J=7.2 \mathrm{~Hz}, \mathrm{ArH}), 9.68$ and $10.36(2 \mathrm{H}, 2 \mathrm{~s}, 2 \mathrm{NH})$.

\section{RESULTS}

Initially, we chose benzaldehyde $(1.0 \mathrm{mmol})$, urea $(1.5 \mathrm{mmol})$ and ethyl acetoacetate $(1.0 \mathrm{mmol})$ as the standard substrates to search for suitable reaction conditions in the presence of different molar catalyst under solvent-free conditions at $70{ }^{\circ} \mathrm{C}$. We tested several molar of catalyst for this multi component 
synthesis. When $5,10,15$ and $20 \mathrm{~mol} \%$ of succinic acid were used, the yields were 31, 55, 76 and $91 \%$, respectively (Table 1, entries 2-5). Therefore, 20 mol\% of succinic acid were convenient (Table 1, entry 5 ) and excessive amount of succinic acid did not increase the yields significantly (Table 1, entry 10). Various temperatures from $\mathrm{rt}$ to $80{ }^{\circ} \mathrm{C}$ were optimized for this reaction. When the systematic screening was made, we found that, in the presence of $70^{\circ} \mathrm{C}$, substrates were transformed into the desired product $\mathbf{4 a}$ in an excellent yield (Table 1, entry 5). With these optimized conditions in hand, we examined the scope of this multi-component process by using various easily available starting materials. As revealed in Table 2, a range of invaluable 3,4-dihydropyrimidin$2-(1 H)$-ones/thiones derivatives can be synthesized in high to excellent yields.

Herein we reported the use of succinic acid as an efficient and bio-based green catalyst for eco-safe and convenient preparation of 3,4-dihydropyrimidin$2-(1 H)$-ones/thiones derivatives using a multi-component reaction of aryl aldehyde derivatives $(1,1.0 \mathrm{mmol})$, urea/ thiourea $(2,1.5 \mathrm{mmol})$ and ethyl/ methyl acetoacetate $(\mathbf{3}, 1.0 \mathrm{mmol})$ under solvent-free conditions (Figure 1).

Table 1. Optimization of the reaction condition on the synthesis of $4 a^{a}$

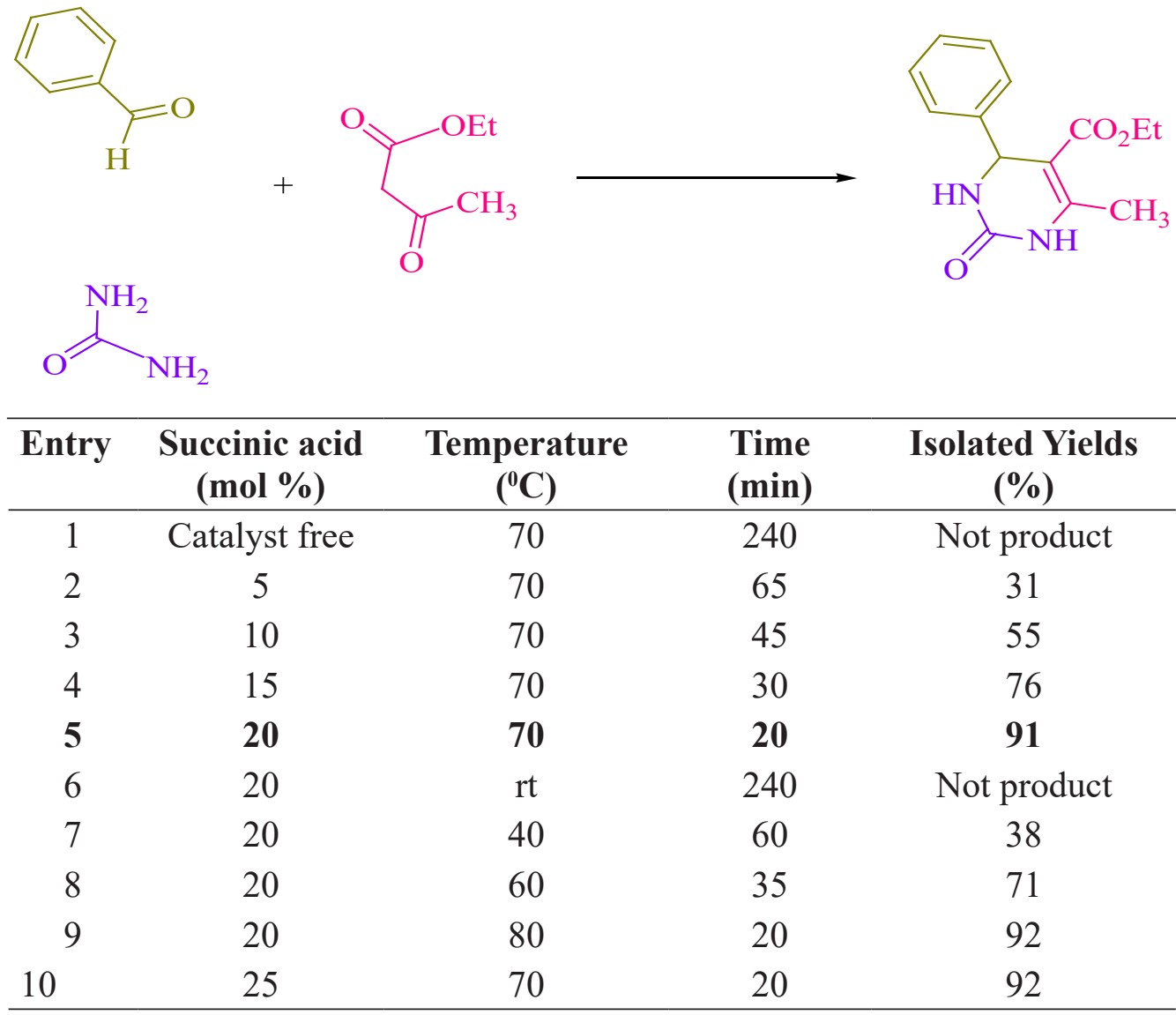

Note: ${ }^{a}$ Reaction conditions: benzaldehyde $(1.0 \mathrm{mmol})$, ethyl acetoacetate $(1.0 \mathrm{mmol})$, urea $(1.5 \mathrm{mmol})$ and succinic acid was heated under various temperatures for the appropriate time. 


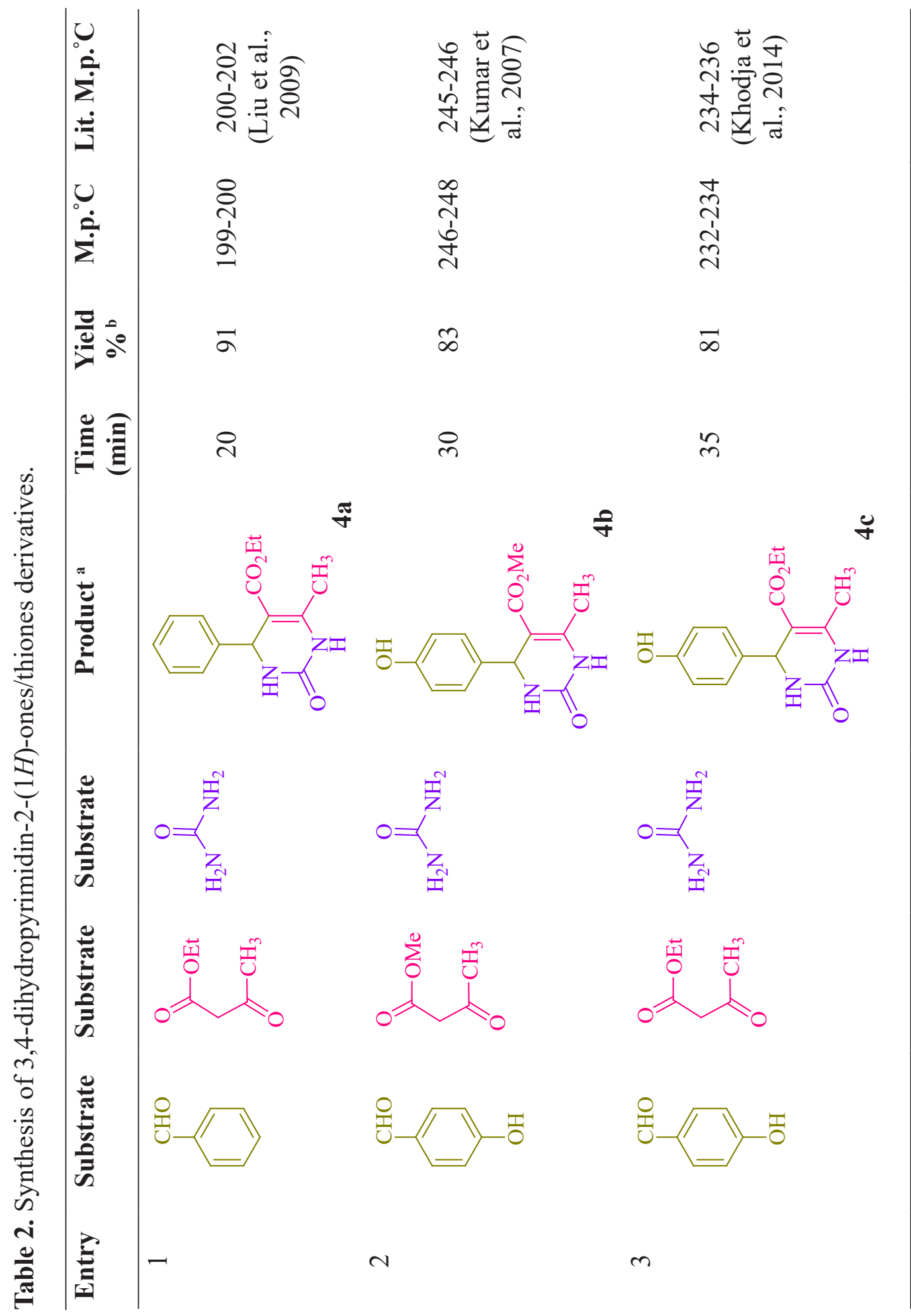




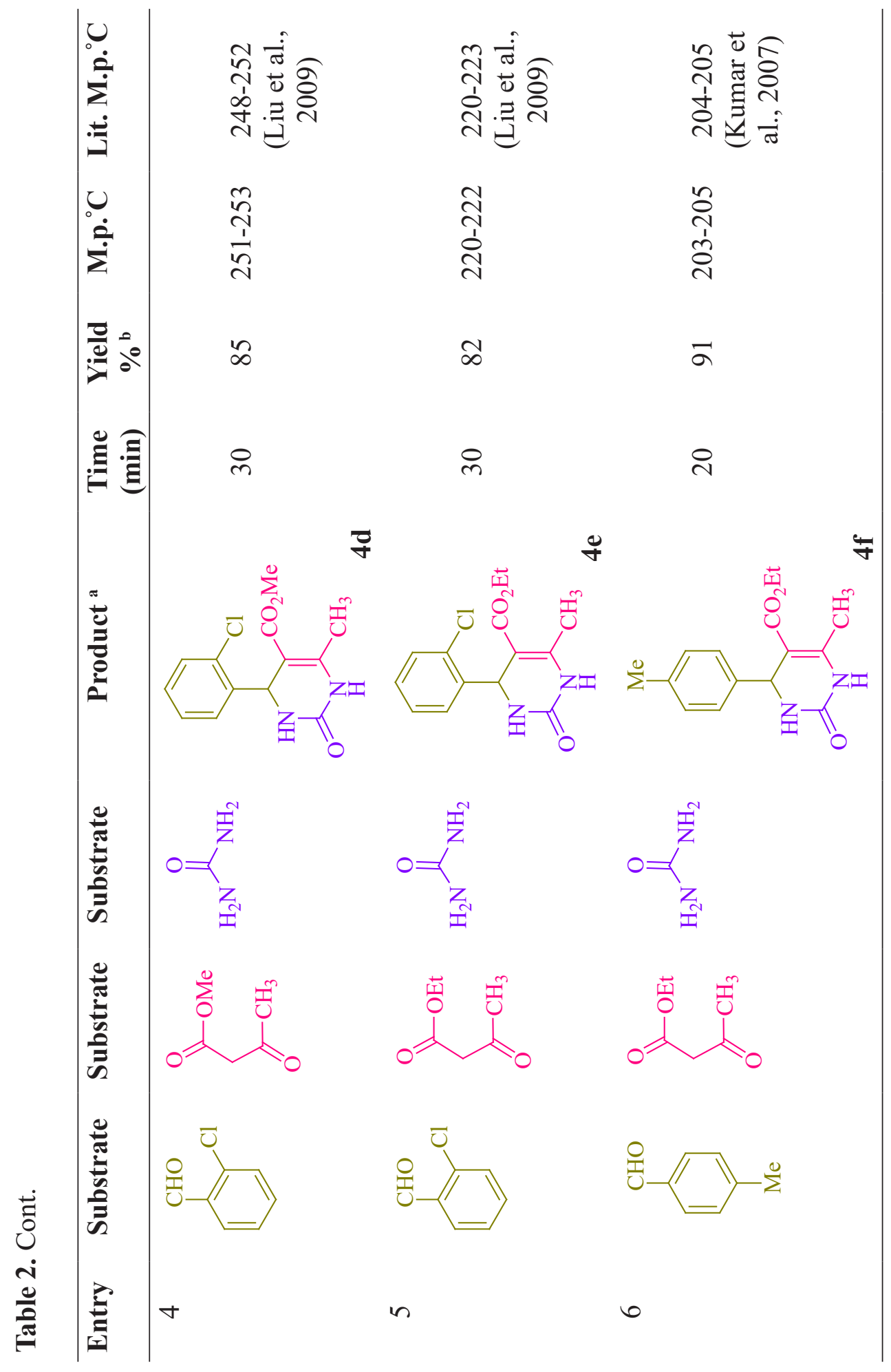




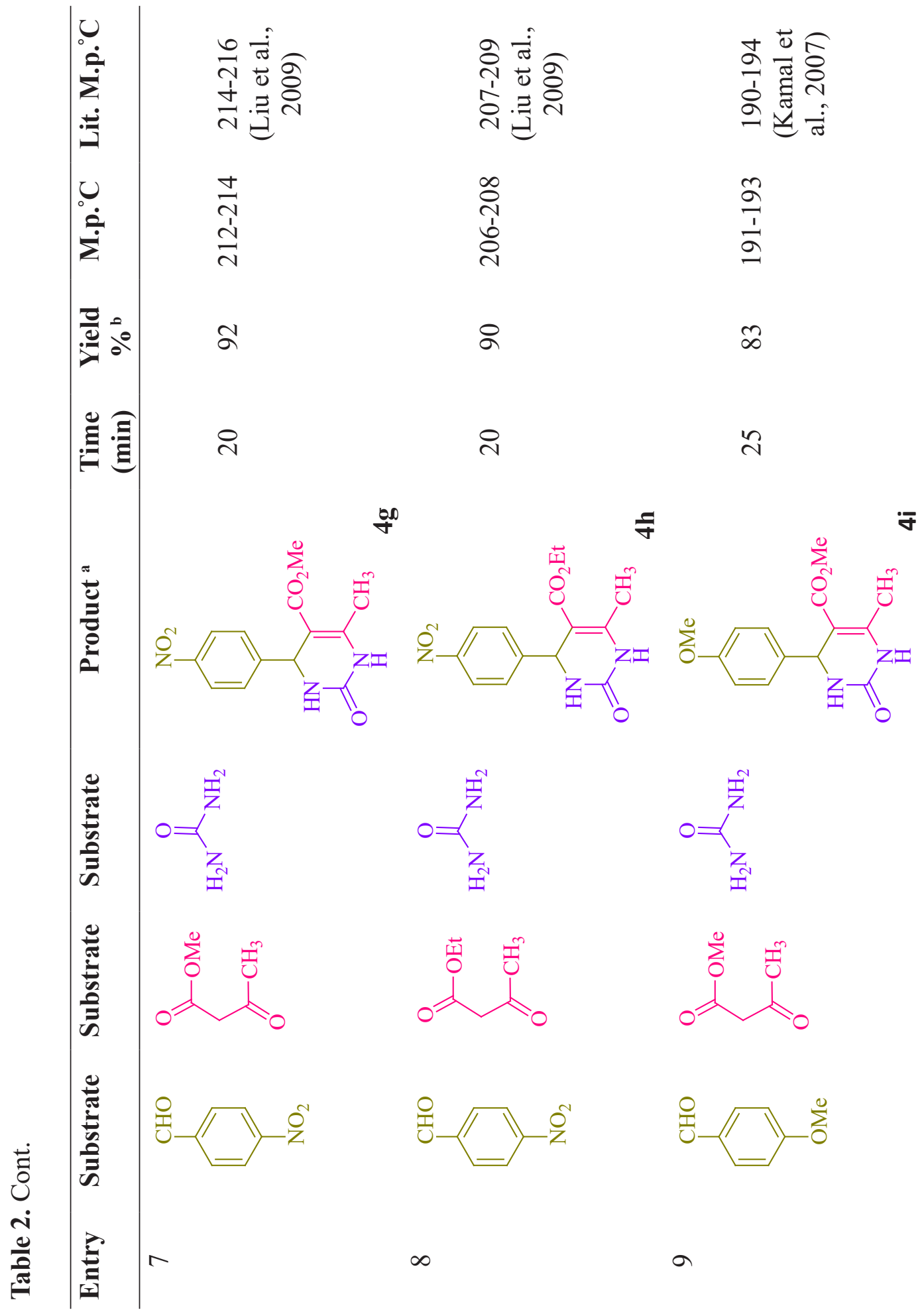




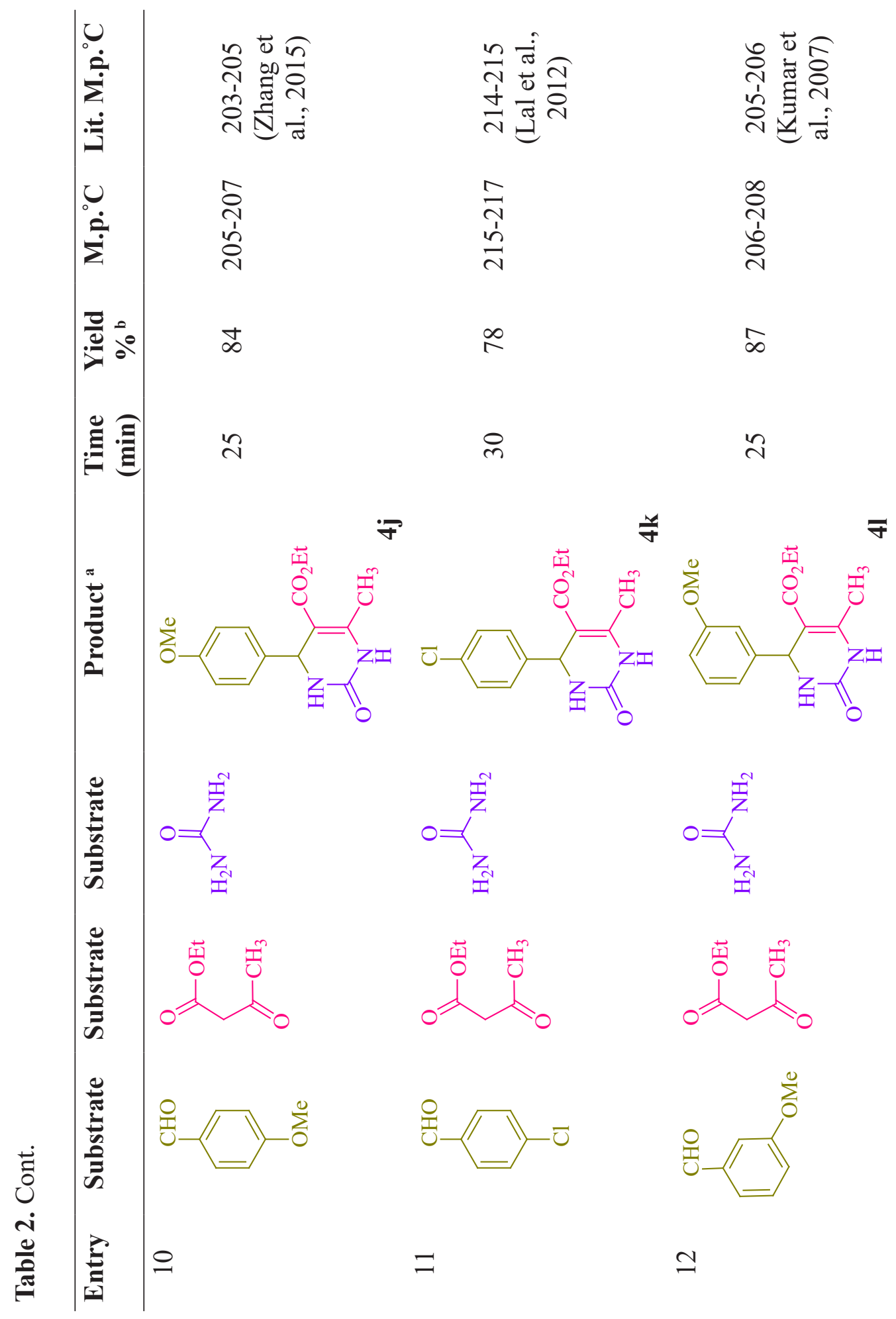




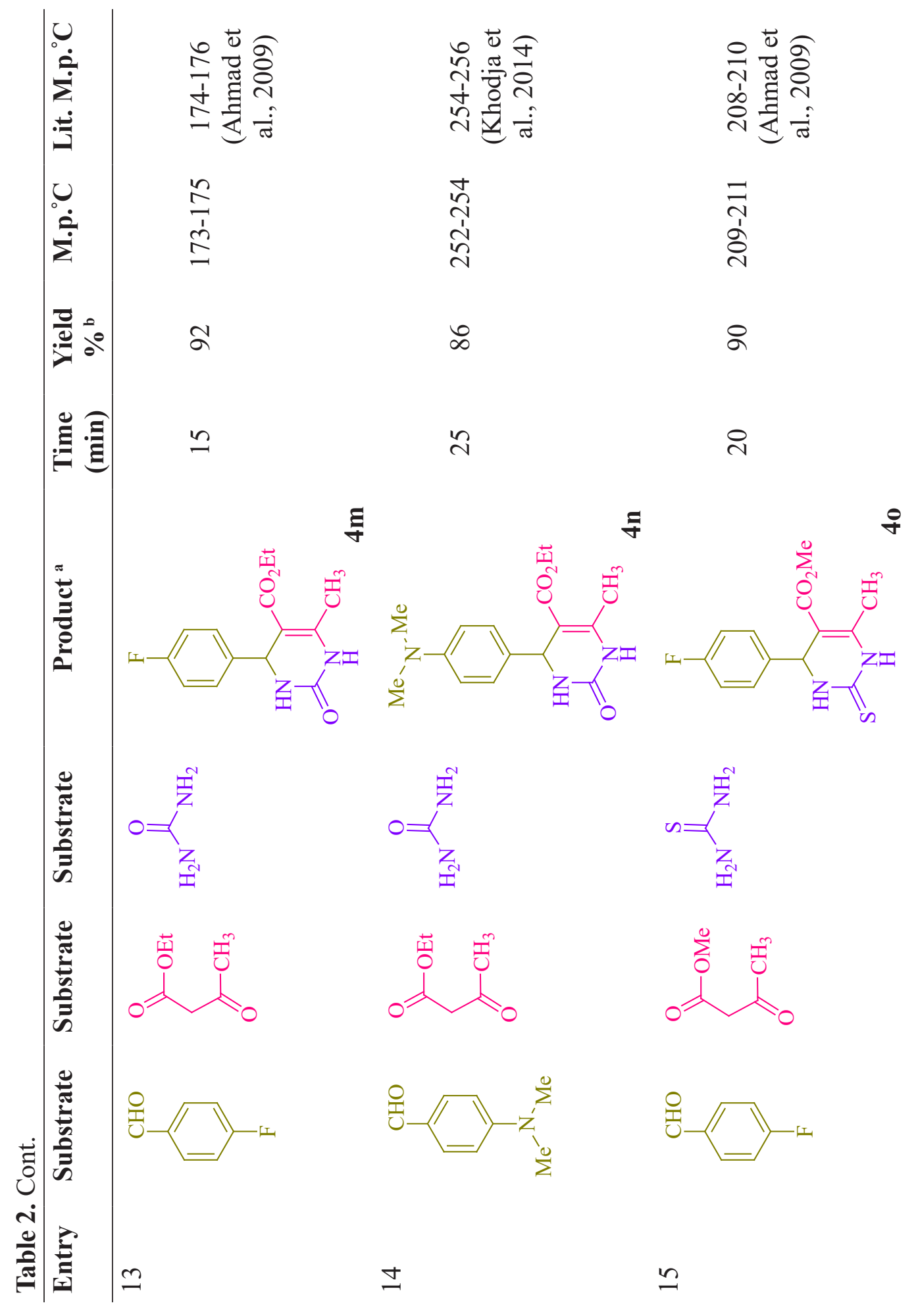




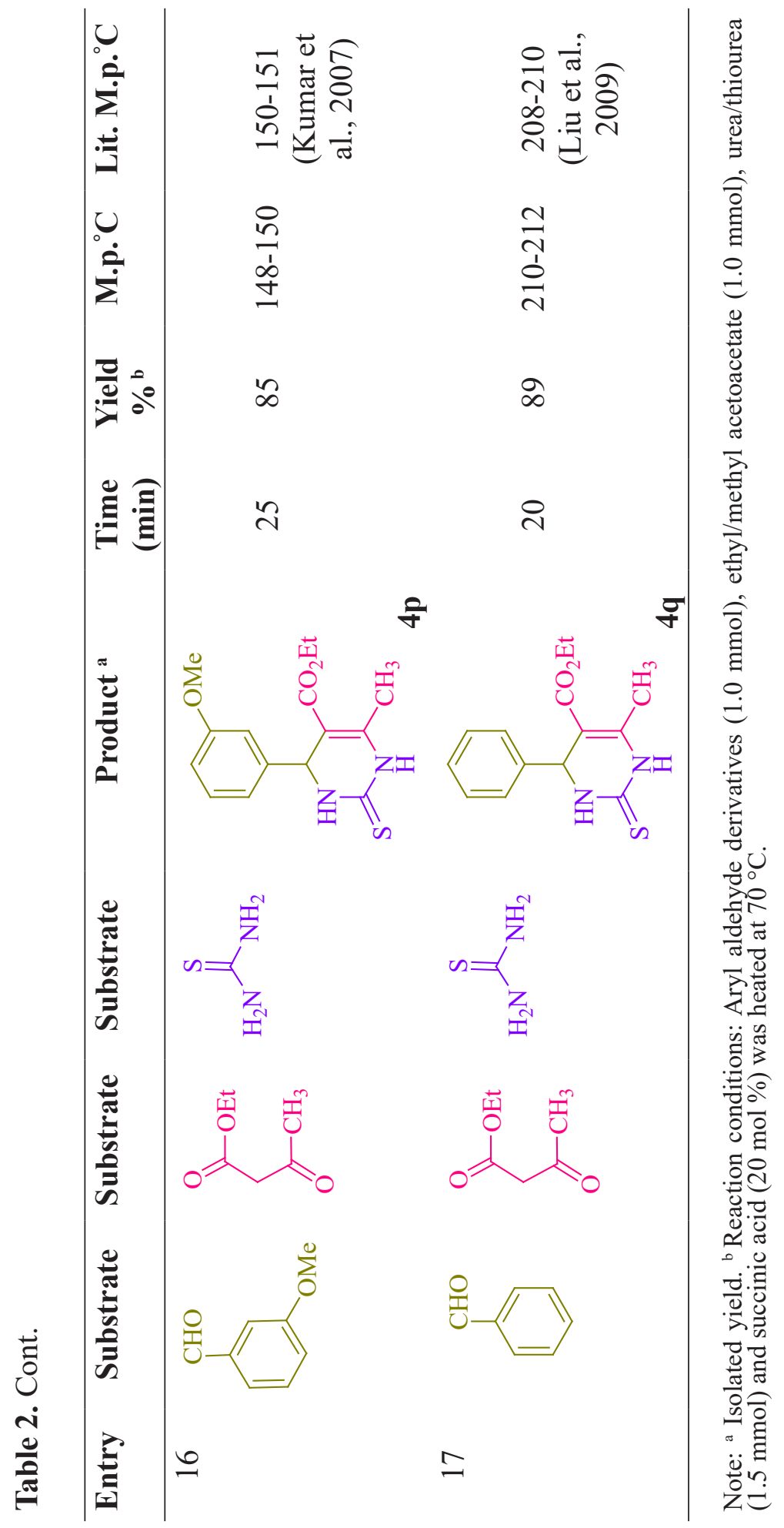




\section{DISCUSSION}

Proposed mechanistic route of 3,4-dihydropyrimidin-2-(1H)-ones/ thiones synthesis in the presence of succinic acid are shown in Figure 2. In this probable mechanism, the succinic acid catalyzed Biginelli condensation via acylimin intermediate (A) is presented in Figure 2. The reaction of aldehydes (1) and urea (2) generates an acylimin intermediate (A), which further reacts with the activated 1,3-dicarbonyl compound (B) producing an open-chain ureide (C) undergoing subsequent cyclization and dehydration to give the major product (4).

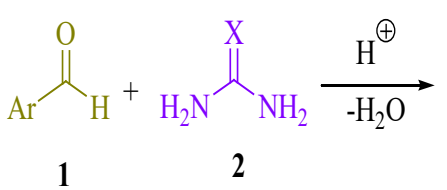<smiles>C=CC(=O)CC(C)=O</smiles>

3<smiles>[X]C(N)=NC=[V]</smiles>

A

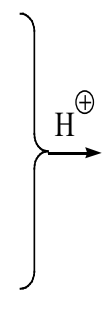

B<smiles>[R20]C(=O)C(C(C)=O)C([Al])NC([X])N</smiles>

C<smiles>[X]C1NC(C)=C(C(=O)O)C([Al])N1</smiles>

4

Figure 2. Proposed mechanistic route for the synthesis of 3,4-dihydropyrimidin2-(1H)-ones/thiones.

Comparison of catalytic ability some of catalysts reported in the literature for synthesis of 3, 4-dihydropyrimidin-2-( $1 H)$-ones/thiones derivatives are shown in Table 3. This study reveals that succinic acid has shown its extraordinary potential to be an alternative green, bio-based, readily, highly efficient and inexpensive catalyst for the Biginelli reaction. In Addition, the use of solvent-free conditions with high to excellent yields and short reaction times in the reaction with both urea and thiourea are the notable advantages this eco-safe and simple procedure. 
Table 3. Comparison of catalytic ability some of catalysts reported in the literature for synthesis of 3, 4-dihydropyrimidin-2-(1H)-ones/thiones derivatives a

\begin{tabular}{|c|c|c|c|c|}
\hline Entry & Catalyst & Conditions & $\begin{array}{c}\text { Time/Yield } \\
(\%)\end{array}$ & References \\
\hline 1 & bakers' yeast & Room temperature & $24 \mathrm{~h} / 84$ & $\begin{array}{l}\text { (Kumar } \\
\text { et al., 2007) }\end{array}$ \\
\hline 2 & Hydrotalcite & Solvent-free, $80^{\circ} \mathrm{C}$ & $35 \mathrm{~min} / 84$ & $\begin{array}{l}\text { (Lal et al., } \\
\text { 2012) }\end{array}$ \\
\hline 3 & {$\left[\mathrm{Al}\left(\mathrm{H}_{2} \mathrm{O}\right)_{6}\right]\left(\mathrm{BF}_{4}\right)_{3}$} & MeCN, Reflux & $20 \mathrm{~h} / 81$ & $\begin{array}{l}\text { (Litvic et al., } \\
\text { 2010) }\end{array}$ \\
\hline 4 & $\mathrm{Cu}\left(\mathrm{BF}_{4}\right)_{2} \cdot \mathrm{xH}_{2} \mathrm{O}$ & Room temperature & $30 \mathrm{~min} / 90$ & $\begin{array}{l}\text { (Kamal } \\
\text { et al., 2007) }\end{array}$ \\
\hline 5 & {$[\mathrm{Btto}][p-\mathrm{TSA}]$} & Solvent-free, $90^{\circ} \mathrm{C}$ & $30 \mathrm{~min} / 96$ & $\begin{array}{l}\text { (Zhang } \\
\text { et al., 2015) }\end{array}$ \\
\hline 6 & triethylammonium acetate & Solvent-free, $70^{\circ} \mathrm{C}$ & $45 \mathrm{~min} / 90$ & $\begin{array}{l}\text { (Attri et al., } \\
\text { 2017) }\end{array}$ \\
\hline 7 & $\begin{array}{l}p \text {-dodecylbenzenesulfonic } \\
\text { acid }\end{array}$ & Solvent-free, $80^{\circ} \mathrm{C}$ & $3 \mathrm{~h} / 94$ & $\begin{array}{l}\text { (Aswin } \\
\text { et al., 2014) }\end{array}$ \\
\hline 8 & TMSPTPOSA & EtOH/Reflux & $3 \mathrm{~h} / 95$ & $\begin{array}{l}\text { (Rao Jetti } \\
\text { et al., 2017) }\end{array}$ \\
\hline 9 & Succinic acid & $\begin{array}{l}\text { Solvent-free, } \\
70^{\circ} \mathrm{C}\end{array}$ & $20 \mathrm{~min} / 91$ & This work \\
\hline
\end{tabular}

Note: ${ }^{a}$ Based on the three-component reaction of benzaldehyde, ethyl acetoacetate and urea.

\section{CONCLUSION}

In summary, the use of succinic acid as a bio-based green and mild catalyst for facile preparation of 3,4-dihydropyrimidin-2-( $1 H)$-ones/thiones derivatives via one-pot three-component Biginelli condensation of aryl aldehydes, urea/thiourea and ethyl/methyl acetoacetate is studied. The use of readily, easily to handle, non-toxic and inexpensive catalyst, simple work-up and solvent-free conditions provides a sustainable procedure compared to conventional methods.

\section{ACKNOWLEDGEMENTS}

We gratefully acknowledge financial support from the Research council of the Young Researchers and Elite Club of Islamic Azad University of Shiraz. 


\section{REFERENCES}

Agarwal, L., Isar, J., Meghwanshi, G.K., and Saxena, R.K. 2006. A cost effective fermentative production of succinic acid from cane molasses and corn steep liquor by Escherichia coli. Journal of Applied Microbiology. 100(6): 1348-1354. https://doi.org/10.1111/j.1365-2672. 2006.02894.X

Ahmad, B., Khan, R.A., Habibullah, A., and Keshai, M. 2009. An improved synthesis of biginelli-type compounds via phase-transfer catalysis. Tetrahydron Letters. 50(24): 2889-2892. https://doi.org/10.1016/j.tetlet. 2009.03.177

Ashok, M., Holla, B.S., and Kumar, N.S. 2007. Convenient one pot synthesis of some novel derivatives of thiazolo[2,3-b]dihydropyrimidinone possessing 4-methylthiophenyl moiety and evaluation of their antibacterial and antifungal activities. European Journal of Medicinal Chemistry. 42(3): 380-385. https://doi.org/10.1016/j.ejmech.2006.09.003

Aswin, K., Mansoor, S.S., Logaiya, K., Sudhan, P.N., and Ahmed, R.N. 2014. Facile synthesis of 3, 4-dihydropyrimidin-2 (1H)-ones and-thiones and indeno [1, 2-d] pyrimidines catalyzed by p-dodecylbenzenesulfonic acid. Journal of Taibah University for Science. 8: 236-247. https:// doi.org/10.1016/j.jtusci.2014.03.005

Attri, P., Bhatia, R., Gaur, J., Arora, B., Gupta, A., Kumar, N., and C hoi, E.H. 2017. Triethylammonium acetate ionic liquid assisted one-pot synthesis of dihydropyrimidinones and evaluation of their antioxidant and antibacterial activities. Arabian Journal of Chemistry. 10(2): 206-214. https://doi.org/10.1016/j.arabjc.2014.05.007

Bewley, C.A., Ray, S., Cohen, F., Collins, S.K., and Overmann, L.E. 2004. Inhibition of HIV-1 envelope-mediated fusion by synthetic batzelladine analogues. Journal of Natural Products. 67(8): 1319-1324. https://doi.org/ 10.1021/np049958o

Biginelli, P. 1893. Aldehyde-urea derivatives of aceto- and oxaloacetic acids. Gazzetta Chimica Italiana. 23(1): 360-413

Chitra, S., and Pandiarajan, K. 2009. Calcium fluoride: an efficient and reusable catalyst for the synthesis of 3, 4-dihydropyrimidin-2(1H)-ones and their corresponding $2(1 \mathrm{H})$ thione: an improved high yielding protocol for the Biginelli reaction. Tetrahdron Letters. 50(19): 22222224. https://doi.org/10.1016/j.tetlet.2009.02.162

Du, C., Lin, S.K.C., Koutinas, A.,Wang, R., Dorado, P., and Webb, C. 2008. A wheat biorefining strategy based on solid-state fermentation for fermentative production of succinic acid. Bioresource Technology. 99(17): 8310-8315. https://doi.org/10.1016/j.biortech.2008.03.019 
Heys, L., Moore, C.G., and Murphy, P. 2000. The guanidine metabolites of Ptilocaulis spiculifer and related compounds; isolation and synthesis. Chemical Society Reviews. 29(1): 57-67. https://doi.org/10.1039/ A903712H

Hodge, D.B., Andersson, C., Berglund, K.A., and Rova, U. 2009. Detoxification requirements for bioconversion of softwood dilute acid hydrolyzates to succinic acid. Enzyme and Microbial Technology. 44(5): 309-316. https://doi.org/10.1016/j.enzmictec.2008.11.007

Hurst, E.W., and Hull, R. 1961. Two new synthetic substances active against viruses of the psittacosis-lymphogranuloma-trachoma group. Journal of Medicinal and Pharmaceutical Chemistry. 3(2): 215-219. https://doi.org/10.1021/jm50015a002

Kamal, A., Krishnaji, T., and Azhar, M.A. 2007. Copper (II) tetrafluoroborate as a mild and efficient catalyst for the one-pot synthesis of 3, 4dihydropyrimidin-2(1H)-ones under solvent-free conditions. Catalysis Communications. 8(12): 1929-1993. https://doi.org/10.1016/j.catcom. 2007.03.009

Kapoor, T.M., Mayer, T.U., Coughlin, M.L., and Mitchison, T.J. 2000. Probing spindle assembly mechanisms with monastrol, a small molecule inhibitor of the mitotic kinesin, Eg5. Journal of Cell Biology. 150(5): 975-988. https://doi.org/10.1083/jcb.150.5.975.

Khodja, I.A., Boulcina, R., and Debache, A. 2014. Copper(II) acetate promoted facile synthesis of dihydropyrimidinone derivatives via a solvent free Biginelli multicomponent reaction. Journal of Chemical and Pharmaceutical Research. 6(5): 1040-1045

Kim, D.Y., Yim, S.C., Lee, P.C., Lee, W.G., Lee, S.Y., and Chang, H.N. 2004. Batch and continuous fermentation of succinic acid from wood hydrolysate by Mannheimia succiniciproducens MBEL55E. Enzyme and Microbial Technology. 35(6-7): 648-653. https://doi.org/10.1016/ j.enzmictec.2004.08.018

Kumar, A., and Maurya, R.A. 2007. An efficient bakers yeast catalyzed synthesis of 3, 4-dihydropyrimidin-2-(1H)-ones. Tetrahedron Letters. 48(26): 4569-4571. https://doi.org/10.1016/j.tetlet.2007.04.130

Lal, J., Sharma, M., Gupta, S., Parashar, P., Sahu, P., and Agarwal, D.D. 2012. Hydrotalcite: a novel and reusable solid catalyst for one-pot synthesis of 3,4-dihydropyrimidinones and mechanistic study under solvent free conditions. Journal of Molecular Catalysis A: Chemical. 352(1): 31-37.https://doi.org/10.1016/j.molcata.2011.09.009 
Lashkari, M., Heydari, R., and Mohamadpour, F. 2018, A facile approach for one-pot synthesis of 1H-pyrazolo [1,2-b]phthalazine-5,10-dione derivatives catalyzed by $\mathrm{ZrCl}_{4}$ as an efficient catalyst under solvent-free conditions. Iranian Journal of Science and Technology, Transactions A: Science. 42(3): 1191-1197. https://doi.org/10.1007/ s40995-016-0122-8

Lee, P.C., Lee, S.Y., Hong, S.H., and Chang, H.N. 2003a. Batch and continuous cultures of Mannheimia succiniciproducens MBEL55E for the production of succinic acid from whey and corn steep liquor. Bioprocess and Biosystems Engineering. 26(1): 63-67. https://doi.org/ 10.1007/s00449-003-0341-1

Lee, P.C., Lee, S.Y., Hong, S.H., Chang, H.N., and Park, S.C. 2003 b. Biological conversion of wood hydrolysate to succinic acid by Anaerobiospirillum succiniciproducens. Biotechnology Letters. 25(2): 111-114. https://doi.org/10.1023/A:1021907116361

Lee, P.C., Lee, W.G., Kwon, S., Lee, S.Y., and Chang, H.N. 2000. Batch and continuous cultivation of Anaerobiospirillum succiniciproducens for the production of succinic acid from whey. Applied Microbiology and Biotechnology. 54(1): 23-27. https://doi.org/10.1007/s002530000331

Litvic, M., Vecani, I., Ladisic, Z.M., Lovric, M., Voncovic, V., and Filipan-Litvic, M. 2010. First application of hexaaquaaluminium(III) tetrafluoroborate as a mild, recyclable, non-hygroscopic acid catalyst in organic synthesis: a simple and efficient protocol for the multi gram scale synthesis of 3,4-dihydropyrimidinones by Biginelli reaction. Tetrahedron. 66(19): 3463-3471. https://doi.org/10.1016/j.tet.2010.03. 024

Liu, C.J., and Wang, J-.D. 2009. Copper (II) sulfamate: an efficient catalyst for the one-pot synthesis of 3, 4-dihydropyrimidine-2 $(1 H)$-ones and thiones. Molecules. 14(2): 763-770. https://doi.org/10.3390/molecules 14020763

Liu, Y.P., Zheng, P., Sun, Z.H., Ye, N., Dong, J.J., and Zhu, L.L. 2008. Economical succinic acid production from cane molasses by Actinobacillus succinogenes. Bioresource Technology. 99(6): 17361742. https://doi.org/10.1016/j.biortech.2007.03.044

Magerramow, A.M., Kurbanova, M.M., Abdinbekova, R.T., Rzaeva, I.A., Farzaliev, V.M., and Allokhverdiev, M.A. 2006. Synthesis and antioxidative properties of some 3, 4-dihydropyrimidin-2 $(1 H)$ ones (-thiones). Russian Journal of Applied Chemistry. 79(5): 787-790. https://doi.org/10.1134/S107042720605017X 
Mohamadpour, F. 2018a. Ascorbic acid as a natural grren, highly efficient and economical catalyst promoted one-pot facile synthesis of 12aryltetrahydrobenzo[a]xanthenes-11-ones, 1,8-dioxo octahydroxanthenes and 14-aryl-14H-dibenzo[a,j]xanthenes under solvent-free conditions. UPB Scientific Bulletin, Series B: Chemistry and Materials Science. 80(2): 101-116.

Mohamadpour, F. 2018b. Green and Convenient One-Pot Access to Polyfunctionalized Piperidine Scaffolds via Glutamic Acid Catalyzed Knoevenagel- Intramolecular [4+2] aza-Diels-Alder Imin-Based Multi-Component Reaction Under Ambient Temperature. Polycyclic Aromatic Compounds. https://doi.org/10.1080/10406638.2018.1472111. Mohamadpour, F. 2018c. $\mathrm{ZnSO}_{4} \cdot 7 \mathrm{H}_{2} \mathrm{O}$ Catalyzed One-pot and Facile Synthesis of Highly Substituted Dihydro-2-oxopyrroles at Room Temperature. Makara Journal of Science. 22(2): 82-88. https://doi/org/ $10.7454 / \mathrm{mss} . v 22 \mathrm{i} 2.8792$

Mohamadpour, F., Maghsoodlou, M.T., Heydari, R., and Lashkari, M. 2016. Copper (II) acetate monohydrate: an efficient and ecofriendly catalyst for the one-pot multi-component synthesis of biologically active spiropyrans and 1Hpyrazolo[1,2-b]phthalazine-5,10-dione derivatives under solvent-free conditions. Research on Chemical Intermediates. 42(12): 7841-7853. https://doi.org/10.1007/s11164-0162565-0

Mohamadpour, F., Maghsoodlou, M.T., Heydari, R., and Lashkari, M. 2017. Tartaric Acid: a Naturally Green and Efficient Di-Functional Brønsted Acid Catalyst for the One-Pot Four-Component Synthesis of Polysubstituted Dihydropyrrol-2-Ones at Ambient Temperature. Iranian Journal of Science and Technology, Transactions A: Science. 41(3): 843-849. https://doi.org/10.1007/s40995-016-0049-0

Prakash, O., Kumar, R., and Parkash, V. 2008. Synthesis and antifungal activity of some new 3-hydroxy-2-(1-phenyl-3-aryl-4-pyrazolyl) chromones. European Journal of Medicinal Chemistry. 43(2): 435-440. https://doi.org/10.1016/j.ejmech.2007.04.004

Rao Jetti, S., Verma, D., and Jain, Sh. 2017. 3-[(3-(Trimethoxysilyl)propyl)thio]propane-1-oxy-sulfonic acid: an efficient recyclable heterogeneous catalyst for the synthesis of 3,4-dihydropyrimidin2(1H)-ones/thiones. Arabian Journal of Chemistry. 10(2): S3184-S3189. https://doi.org/10.1016/j.arabjc.2013.12.012

Samuelov, N.S., Datta, R., Jain, M.K., and Zeikus, J.G. 1999. Whey fermentation by Anaerobiospirillum succiniciproducens for production of a succinate-based animal feed additive. Applied and Environmental Microbiology. 65(5): 2260-2263. 
Vermuri, G.N., Eiteman, M.A., and Altman, E. 2002. Effects of growth mode and pyruvate carboxylase on succinic acid production by metabolically engineered strains of Escherichia coli. Applied and Environmental Microbiology. 68(4): 1715-1727. https://doi.org/10.1128/AEM.68.4. $1715-1727$

Wan, C., Li, Y., Shahbazi, A., and Xiu, S. 2008. Succinic acid production from cheese whey using Actinobacillus succinogenes 130 Z. Applied Biochemistry and Biotechnology. 45(1-3): 111-119. https://doi.org/10.1007/978-1-60327-526-2_13

Wisen, S., Androsavich, J., Evans, C.G., Chang, L., and Gestwi cki, J.E. 2008. Chemical modulators of heat shock protein 70 (Hsp70) by sequential, microwave-accelerated reactions on solid phase. Bioorganic \& Medicinal Chemistry Letters. 18(1): 60-65. https://doi.org/10.1016/ j.bmcl.2007.11.027

Zeikus, J.G., Jain, M.K. and Elankovan, P. 1999. Biotechnology of succinic acid production and markets for derived industrial products. Applied Microbiology and Biotechnology. 51(5): 545-552. https://doi.org/10.1007/s002530051431

Zhang, Y., Wang, B., Zhang, X., Huang, J., and Liu, C. 2015. An efficient synthesis of 3,4-Dihydropyrimidin-2(1H)-Ones and thiones catalyzed by a novel brønsted acidic ionic liquid under solvent-free conditions. Molecules. 20(3): 3811-3820. https://doi.org/10.3390/ molecules20033811

Zheng, P., Dong, J.J., Sun, Z.H., Ni, Y., and Fang, L. 2009. Fermentative production of succinic acid from straw hydrolysate by Actinobacillus succinogenes. Bioresource Technology. 100(8): 2425-2429. https:// doi.org/10.1016/j.biortech.2008.11.043

Zheng, P., Fang, L., Xu, Y., Dong, J.J., Ni, Y., and Sun, Z.H. 2010. Succinic acid production from corn stover by simultaneous saccharification and fermentation using Actinobacillus succinogenes. Bioresource Technology. 101(20): 7889-7894. https://doi.org/10.1016/j.biortech. 2010.05.016 